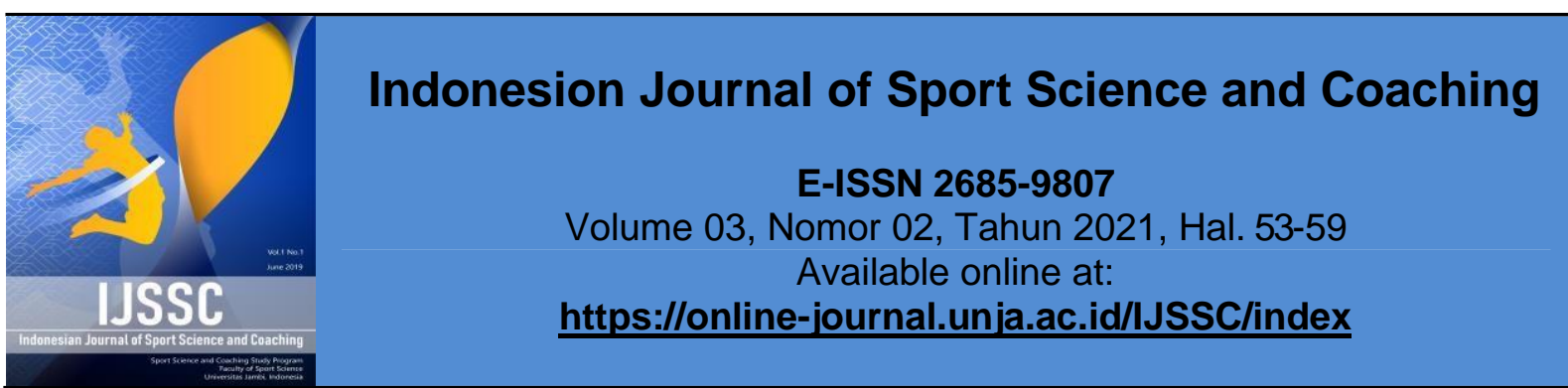

Research Article

OPEN ACCESS

\title{
Survei Program Latihan Atlet Gulat Kabupaten Kerinci
}

\section{Kerinci District Wrestling Athlete Training Program Survey}

\author{
Angga Gustiawan ${ }^{1}$, Muhammad $\mathrm{Ali}^{2}$ \\ Program studi kepelatihan olahraga, FKIP, Universitas Jambi, Indonesia ${ }^{1}$ \\ Pendidikan Olahraga dan Kesehatan, FKIP, Universitas Jambi, Indonesia ${ }^{2}$ \\ Correspondence Author: angga20@gmail.com
}

\begin{tabular}{|c|c|}
\hline Informasi Artikel & ABSTRACT \\
\hline Submit: 05-11-2021 & $\begin{array}{l}\text { This research aims to find out how the form of training program given to } \\
\text { Kerinci Regency wrestling athletes in the current Covid-19 Pandemic } \\
\text { situation.Research conducted is a descriptive study that does not intend to } \\
\text { test a particular hypothesis but only describes what is about a variable, } \\
\text { symptom of a particular state. The instrument in this study is an instrument } \\
\text { carried out by taking data obtained from coaches, administrators and } \\
\text { athletes of Kerinci Regency Wrestling sports.From the results of the } \\
\text { category table it can be seen that the assessment conducted by the } \\
\text { athletes using the question questionnaire obtained the category either with } \\
\text { an average consideration of } 31.4 \text { points or in the category of "agree" from a } \\
\text { maximum of } 40 \text { points. It's just that out of } 10 \text { questions there are still some } \\
\text { questions that disagree with what the coach applies so far as the training } \\
\text { methods given still do not vary, so athletes often feel saturated quickly } \\
\text { when doing training. So from the above explanation, it can be drawn } \\
\text { conclusions from the reference research questionnaire given as follows: } \\
\text { That Kerinci Regency Wrestling athletes are essentially highly motivated by } \\
\text { the sport of wrestling, it's just that lately athletes have started to feel } \\
\text { saturated with less varied training methods. That basically Kerinci Regency } \\
\text { Wrestling athletes really like training that trains slam techniques, therefore } \\
\text { the need for coaches to apply hardy technique training into each training } \\
\text { session. } \\
\text { Keywords: Analysis, Exercise }\end{array}$ \\
\hline Penerbit & ABSTRAK \\
\hline $\begin{array}{l}\text { Jurusan Pendidikan } \\
\text { Olahraga dan } \\
\text { Kepelatihan FKIP } \\
\text { Universitas Jambi } \\
\text { Jambi- Indonesia }\end{array}$ & $\begin{array}{l}\text { Penelitian ini bertujuan untuk mengetahui mengetahui bagaimakah bentuk } \\
\text { program latihan yang diberikan pada atlet gulat Kabupaten Kerinci dalam } \\
\text { situasi Pandemi Covid-19 saat ini. Penelitian yang dilakukan merupakan } \\
\text { penelitian deskriptif penelitian yang tidak bermaksud untuk menguji } \\
\text { hipotesis tertentu tetapi hanya menggambarkan apa adanya tentang } \\
\text { sesuatu variabel, gejala keadaan tertentu. Instrumen dalam penelitian ini } \\
\text { adalah instrumen dilakukan dengan cara Pengambilan data-data yang } \\
\text { diperoleh dari pelatih, pengurus dan atlet cabang olahraga Gulat Kabupaten } \\
\text { Kerinci. Dari hasil tabel kategori dapat dilihat bahwa penilaian yang } \\
\text { dilakukan para atlet menggunakan angket pertanyaan memperoleh kategori } \\
\text { baik dengan pertimbangan rerata sebesar } 31,4 \text { poin atau dalam kategori } \\
\text { "setuju"dari hasil poin maksimal } 40 \text { poin. Hanya saja dari } 10 \text { pertanyaan } \\
\text { masih ada beberapa pertanyaan yang tidak sependapat dengan apa yang } \\
\text { pelatih terapkan selama ini seperti metode latihan yang diberikan masih }\end{array}$ \\
\hline
\end{tabular}


belum bervariasi, sehingga atlet sering merasa cepat jenuh pada saat melakukan latihan. Maka dari penjelasan diatas maka dapat ditarik kesimpulan dari acuan angket penelitian yang diberikan sebagai berikut: Bahwa atlet-atlet Gulat Kabupaten Kerinci pada intinya sangat termotivasi dengan olahraga Gulat, hanya saja akhir-akhir ini atlet mulai merasa jenuh dengan metode latihan yang kurang bervariasi. Bahwa pada dasarnya atletatlet Gulat Kabupaten Kerinci sangat menyukai latihan yang melatih teknik bantingan, oleh karena itu perlunya pelatih menerapkan latihan teknik bantingan ke dalam tiap sesi latihan

Kata sandi: Analisis, Program Latihan.

This Indonesian Journal of Sport Science and Coaching is licensed under a CC BY-NC-SA (Creative Commons Attribution-ShareAlike 4.0 International License)

\section{PENDAHULUAN}

Olahraga adalah salah satu sarana penting dalam peningkatan kualitas sumber daya manusia. Olahraga bukan hanya untuk meningkatkan kesegaran semata namunlebih dari itu, olahraga dapat dijadikan sebagai sarana untuk meningkatkan martabat suatu bangsa dan sebagai ajang pengukur prestasi, cabang olahraga.

"Keolahragaan nasional bertujuan memelihara dan meningkatkan kesehatan dan kebugaran, prestasi kualitas manusia, menanamkan nilai moral dan akhlak mulia, sportivitas, disiplin, mempererat dan membina persatuan dan kesatuan bangsa, memperkukuh ketahanaan nasional, serta meningkatkan harkat, martabat, dan kehormatan bangsa" (UU RI.3 Tahun 2005 pasal 4). Uraian di atas menyatakan bahwa untuk memiliki kesehatan yang memadai sebagai upaya untuk mengatasi masalah yang muncul menghadapi beban fisik dalam kehidupan modern dapat dibantu dengan melakukan kegiatan berolahraga.

Olahraga gulat adalah olahraga bela diri tertua di dunia dan telah menjadi olahraga kesehatan dan prestasi dan telah dipertandingkan sejak olimpiade kuno sampai sekarang. Kejurnas gulat pertama kali pada tahun 1961 telah dipertandingkan dibandung dan menyusul PON ke V dengan tahun yang sama Gulat juga telah dipertandingkan. Berdasarkan gaya Gulat, gaya yang dipetandingkan disetiap kejuaraan gulat adalah gaya bebas dan gryco roman. Gulat gaya bebas adalah permainan gulat yang diperkenankan pegulat menyerang kedua kaki lawan yaitu menjegal, menarik kaki sesuai aturan yang ditentukan dan bisa menggunakan kedua kaki dan seluruh tubuh, sedangkan gulat gaya gryco roman adalah permainan gulat yang melarang pegulat menyerang bagian bawah tubuh seperti dibawah panggul, paha dan kaki. Yang menjadi persamaan adalah teknik susupan, bantingan, gulungan dan kuncian.

Gulat merupakan olahraga prestasi yang mempunyai ciri khas yaitu olahraga yang berhadapan dengan menggunakan anggota tubuh, berusaha untuk menjatuhkan lawan dengan cara menarik, mendorong, menjegal, membanting, menekan, menahan, sehingga lawan menempel di atas matras dengan tidak melanggar peraturan yang telah ditentukan. Pada olahraga gulat, terdapat dua gaya yang dipertandingkan baik nasional maupun internasional, yaitu Gaya Bebas (Free Style) dan Gaya Romawi Yunani (Greco Romaine). Gaya bebas adalah tata cara permainan gulat yang memperkenankan pegulat menyerang kedua kaki lawan yaitu menjegal, menarik kaki sesuai dengan aturan yang ditentukan.

Sedangkan gaya romawi yunani (Greco Romaine) adalah tata cara permainan gulat yang melarang pegulat menyerang bagian tubuh bawah panggul seperti menjegal,menarik kaki, melipat lawan. Olahraga gulat gaya bebas terdapat berbagai teknik serangan atas yaitu: tangkapan kaki, tangkapan satu kaki, tangkapan 
dua kaki, tarikan lengan, bantingan bahu, bantingan leher, bantingan lengan, kayang depan, kayang samping, dan kayang belakang (zubless). Sedangkan pada gaya romawi yunani (greeco roman) terdapat berbagai teknik serangan atas yaitu : bantingan pinggang, bantingan leher, bantingan lengan, bantingan sway, kayang depan, kayang samping, zubless dan lain-lain.

Seorang pegulat harus menguasai teknik serangan, counter, dan bertahan yang baik untuk mengungguli lawannya. Untuk mendapatkan bantingan yang baik ada beberapa aspek yang harus dikembangkan melalui latihan, aspek-aspek tersebut adalah: 1). Persiapan fisik, 2). persiapan teknik. Aspek kemampuan biomotor yang meliputi kekuatan, kecepatan, dan komposisi tubuh juga harus dilatih dan dikembangkan. Menurut M. Sajoto (1988:16), kondisi fisik adalah satu kesatuan utuh dari komponen komponen yang tidak dapat dipisahkan begitu saja, baik peningkatan maupun pemeliharaannya, ada 10 komponen kondisi fisik, yaitu : (1) kekuatan (strenght), (2) daya tahan (endurance), (3) daya ledak otot (muscular power), (4) kecepatan (speed), (5) daya lentur (flexibility), (6) kelincahan (agility), (7) koordinasi (coordination), (8) keseimbangan (balance), (9) ketepatan (accuracy), (10) reaksi (reaction), dari sepuluh kondisi fisik tersebut yang dominan dalam bantingan pinggang seperti: 1) kekuatan, dan 2) Power.

Berdasarkan hasil observasi pada atlet gulat Kabupaten Kerinci, penulis melihat pada saat atlet melaksanakan latihan dan bertanding, atlet jarang sekali melakukan teknik bantingan dengan baik, terkadang atlet melakukan teknik bantingan mengalami kesulitan atau kesalahan. Sepertinya atlet tidak memiliki kudakuda yang kuat pada saat melakukan teknik bantingan pinggang. Setelah penulis melakukan wawancara kepada atlet bahwasanya mereka belum diberikan latihan beban yang bertujuan untuk meningkatkan teknik bantingan.

Sehingga secara tidak langsung maka dapat dikatakan atlet gulat Kabupaten Kerinci masih kurang dalam melakukan teknik bantingan. Berdasarkan pernyataan di atas dapat diketahui bahwa keberhasilan dalam melakukan teknik bantingan dipengaruhi oleh beberapa faktor seperti: Power tungkai dan kekuatan otot punggung. Sentakan gerakan kaki seperdetik yang kuat dan cepat dengan topangan tubuh dan menambah daya dorong saat membanting yang kemudian menjatuhkan ke matras akan menghasilkan bantingan pinggang yang maksimal. Melihat dari kondisi dunia pada saat ini sedang mengalami situasi Pandemi Covid-19 ini tentunya setiap kegiatan harus sesuai dengan protokol kesehatan, begitupun dalam melakukan latihan tentunya sesuai dengan kebijakan yang berlaku yang telah dibuat oleh pihak KONI agar tidak terjadi penyebaran virus yang signifikan dan atlet pun dapat terhindar dari virus Covid-19. Adapun alasan memilih judul dalam penelititan ini dikarenakan kondisi Pandemi Covid-19 tentunya terdapat perbedaan metode yang diberikan pada saat latihan, sehingga disini penulis sangat tertarik dalam menganalisis program latihan tersebut dan ingin menuangkan kedalam sebuah proposal penelitian dengan judul "Survei Program Latihan Atlet Gulat Kabupaten Kerinci".

Dalam kamus bahasa indonesia kontemporer survei adalah penguraian pokok persoalan atas bagian-bagian, penelahaan tersebut dan hubungan antar bagian untuk mendapatkan pengertian yang tepat dengan pemahaman secara keseluruhan (Salim, 2002:156).

Dalam Kamus Besar Bahasa Indonesia karangan Suharso dan Retnoningsih (2005), survei adalah penyelidikan terhadap suatu peristiwa (karangan, perbuatan dan sebagainya) untuk mengetahui keadaan yang sebenarnya (sebab musabab, duduk perkara dan sebagainya). 
Survei mempunyai fungsi untuk mengumpulkan data-data yang terdapat pada suatu lingkungan tertentu. Survei bertujuan untuk menumpulkan data yang pada akhirnya data-data ini dapat digunakan untuk berbagai keperluan pelaku survei.

Dari beberapa penjelasan di atas dapat dipahami bahwa survei adalah suatu kegiatan untuk melihat, menilai, memahami dan mencari suatu kebenaran untuk mengetahui keadaan yang sebenarnya dari yang kita survei terhadap obyek yang diberikan suatu tes atau kegiatan sehingga kita memperoleh hasil yang sebenarnya dan tidak semua.

Berdasarkan faktar-fakta sejarah, gulat adalah cabang olahraga yang cukup tua. Di bawah ini diuraikan secara singkat sejarah olahraga gulat yang sebagian besar dikutip dari buku The Olympic Guide dan ditambah juga dari buku Der Freis Ringkamf Handbuchfur Trainer und Ubungsliter serta wawancara dengan anggota pengurus persatuan Gulat Seluruh Indonesia tingkat pusat dan daerah.

Pada tahun 2500 SM gulat telah menjadi suatu mata pelajaran di suatu sekolah di negara Cina. Begitu juga sekitar tahun 2050 SM gulat telah dipelajari oleh orang- orang Mesir. Hal ini ketahui berdasarkan peninggalan bangsa Mesir pada waktu itu. Salah satu peninggalannya tersebut berupa gambar-gambar yang menunjukkan teknik-teknik bergulat yang terdapat pada dinding Raja Bani Hasan. Selain itu sejarah juga menunjukkan bahwa negara-negara lainpun terdapat suatu jenis perkelahian yang serupa dengan bentuk-bentuk bergulat, seperti Sumo di Jepang, Glima di Iceland, Sohwingen di Swiss, Lancasshire di Scotch, Gumberland di Irish, Caterhras Chath Can di Amerika Serikat dan Greco Roman di Yunani. (http://wrestlingsportinformationcenter.wordpress.com/)

Sejak Olympiade kuno, gulat telah menjadi suatu acara pertandingan, walaupun acara tersebut diadakan di dalam acara Pentathlon. Peserta yang mengikuti pertandingan Pentathlon itu harus mengikuti pertandingan lompat jauh, lempar lembing, lari cepat, lempar cakram dan bergulat.

Pada Olympiade - I tahun 1896 di Athena, gulat gaya Yunani-Romawi menjadi suatu acara pertandingan tersendiri. Pegulat-pegulat tuan rumah pada umumnya memenangkan pertandingan. Hal ini disebabkan karena peraturan yang dipakai pada waktu itu tidak sama dengan peraturan yang dipakai di negara- negara peserta. Setelah itu pada setiap penyelenggaraan Olympiade, tuan rumah yang selalu menentukan peraturan pertandingan yang ditentukan. Bahkan gaya gulat yang dipertandingkan tuan rumah juga yang menentukannya, walaupun negara peserta lainnya belum menguasai gaya gulat itu.

Pada Olympiade - III tahun 1904 di St. Louis, Amerika Serikat maka acara pertandingan gulat hanya untuk gaya 'catehras catch can' saja. Gaya gulat ini lebih dikenal dengan gaya "Freestyle" dan sangat digemari oleh rakyat Amerika Serikat. Sementara negara- negara lain merasa kecewa karena mereka pada umumnya mempelajari gaya Yunani-Romawi. Memang antara kedua gaya ini sangat jauh perbedaannya. Dalam gulat gaya Yunani-Romawi, peserta hanya diperbolehkan menyerang lawan dari batas pinggang ke atas dan tidak boleh menggunakan kaki sebagai alat untuk menyerang. Sedangkat gulat gaya freestyle atau catch as catch can hampir semua tangkapan diperbolehkan, malahan kunci-kunci mematahkan lawan juga diperbolehkan. (Hadi, 2007:2)

Inggris sebagai tuan rumah Olympiade IV tahun 1908, mengadakan pertandingan gulat untuk dua gaya yaitu Yunani-Romawi dan catch as catch can. Diluar dugaan Amerika Serikat sebagai juara gaya catch as catch can mendapat perlawanan yang keras dari negara-negara yang berasal dari Eropa. Meskipun demikian kekacauan dari negara peserta masih ada sebab peraturan pertandingan belum seragam. (Hadi, 2007:2). 
Peraturan gulat internasional baru diadakan pada Olympiade XI tahun 1936 di Berlin, Jerman. Pada waktu itu juga dibentuk Federasi Gulat Internasional atau Federation Internationale de Lutte Amateur (FILA). Sejak itu FILA memperbaiki peraturan gulat internasional.

Dalam mencapai suatu prestasi yang tinggi di perlukan suatu program latihan, pembinaan dan peningkatan olahraga yang seksama, teratur, sistematis, dan berkesinambungan.artinya, prestasi atlet tidak dapat di peroleh secara instant tanpa terdapatnya proses yang baik dari semua komponen pendukungnya, terutama atlet, pelatih, sarana dan prasarana, serta peran pelatih dalam masa pengkondisian atlet dan harusnya seorang pelatih mengenal unsure-unsur dalamolahraga seperti, kekuatan (Streng), kelemahan (Weakes), peluang (Oportunity), ancaman (Threat) yang merupakan satu kesatuan yang tidak dapat di pisahkan satu dengan yang lainnya agar tidak terjadi kekeliruan dan kesalahan didalam pengkondisian yang akan berdampak pada atlet itu sendiri dan yang sangat terpenting dalam pelaksanaan program latihan untuk mencapai kondisi atlet yang maksimal dan keharmonisan hubungan antara atlet, pelatih dan pengurus juga akan berdampak pada keberhasilan atlet.

Kondisi fisik merupakan aspek penting dalam pembentukan prestasi atlet. Tujuan memiliki kondisi fisik yang prima pada atlet yaitu untuk menjaga kestabilan olahraga selama pertandingan, tidak mengalami kelelahan yang berlebihan, efektif dan efisien dalam melakukan gerak tubuh. Dalam pertandingan gulat selain menguasai teknik dasar juga harus memiliki kondisi fisik yang baik.

\section{METODE}

Penelitian ini dilaksanakan di lapangan Gulat Kabupaten Kerinci. Penelitian dilakukan mulai sesuai dari jadwal yang diberikan oleh pihak Fakultas IImu Keolahragaan. Jenis penelitian ini adalah penelitian deskriptif, dimana penelitian ini bertujuan untuk mengungkapkan sesuatu apa adanya. Sebagai yang dikemukakan Suharsimi, Arikunto (1990:310) bahwa 'Penelitian deskriptif adalah penelitian yang tidak bermaksud untuk menguji hipotesis tertentu tetapi hanya menggambarkan apa adanya tentang sesuatu variabel, gejala keadaan tertentu".

Penelitian deskriptif merupakan penelitian yang ingin mengetahui seberapa besar kemampuan yang dimiliki oleh setiap pemain yang dapat dinilai melalui angka atau numerik sehingga dapat dikualifikasikan ke dalam kategori baik, sedang atau kurang. Penelitian ini dimaksudkan untuk mengangkat fakta, keadaan, variabel, dan fenomena-fenomena yang terjadi saat sekarang (ketika penelitian berlangsung) dan menyajikan apa adanya.

Dalam penelitian ini data merupakan data sekunder yang diperoleh dari pelatih, pengurus dan atlet cabang olahraga Gulat Kabupaten Kerinci. Untuk itu diperlukan suatu data teknik analisis data merupakan salah satu langkah penting dalam penelitian, karena dengan menganalisis data akan dapat ditarik kesimpilan mengenai masalah yang akan diteliti. Untuk itu diperlukan suatu teknik analisis data yang sesuai dengan bentuk data yang terkumpul. Analisis statistic dapat memberikan efesiensi dan efektifitas kerja Karena dapat membuat data lebih ringan. Teknik yang digunakan untuk memperoleh data penelitian ini adalah statistic deskripsi dengan analysis percentage.

\section{HASIL DAN PEMBAHASAN}

Hasil penelitian ini diperoleh dengan teknik wawancara dan menggunakan angket kepada atlet gulat kabupaten Kerinci dengan informan sebagai bentuk pencarian data dan dokumentasi langsung dilapangan yang kemudian peneliti analisis. Survei ini sendiri terfokus pada seluruh atlet gulat kabupaten Kerinci yang 
berjumlah 10 orang yang terdiri dari 7 orang putra dan 3 orang putri. Diskriptif data dimaksudkan dalam penelitian ini untuk memperoleh gambaran tentang tanggapan atlet terhadap program latihan yang selama ini diberikan pelatih apakah sudah cukup baik atau tidak apakah perlu adanya diberikan variasi atau inovasi supaya para atlet dapat berlatih lebih semangat dan lebih baik lagi. Maka didapatkan datadata yang mendukung terselesainya penelitian ini.

Berdasarkan penelitian yang telah dilakukan melalui beberapa proses yang sesuai dengan kaidah yang telah ditentukan dan kebutuhan peneliti, maka dapat digambarkan keadaan olahraga gulat yang terdapat di Kabupaten Kerinci khususnya tentang analisis program latihan atlet gulat Kabupaten Kerinci. Penelitian ini bertujuan untuk mengetahui bagaimana pendapat atlet gulat kabupaten kerinci terhadap program latihan yang selama ini diberikan oleh pelatih. Dari hasil tabel kategori dapat dilihat bahwa penilaian yang dilakukan para atlet menggunakan angket pertanyaan memperoleh kategori baik dengan pertimbangan rerata sebesar 31,4 poin atau dalam kategori "setuju"dari hasil poin maksimal 40 poin.

Hanya saja dari 10 pertanyaan masih ada beberapa pertanyaan yang tidak sependapat dengan apa yang pelatih terapkan selama ini seperti metode latihan yang diberikan masih belum bervariasi, sehingga atlet sering merasa cepat jenuh pada saat melakukan latihan. Disini mungkin perlunya pelatih memikirkan metode atau inovasi lain guna mendongkrak motivasi dan semangat atlet dalam mengikuti latihan yang diberikannya. Dan disini pelatih juga bisa memadupadankan dengan keinginan atlet yang sangat menyukai latihan teknik bantingan dengan memberikan beban yang lebih lagi dan jenis bantingan yang lebih bervariatif lagi, sehingga disini pelatih mungkin lebih mengutamakan latihan teknik bantingan ketimbang teknik lainnya dengan catatan perlu metode teknik latihan bantingan yang lebih berinovasi dan bervariasi sehingga atlet pun tidak cepat merasa jenuh. Karena apabila sebuah latihan diberikan beban lebih dan jenis yang bervariatif maka akan menghasilkan suatu inovasi baru sehingga memberikan dampak yang baik kepada atlet yang berlatih.

\section{SIMPULAN}

Berdasarkan observasi, wawancara dan penyebaran angket sebagai data penelitian mengenai survei program latihan atlet gulat kabupaten Kerinci, bahwa persatuan Gulat Kabupaten Kerinci memiliki sarana dan prasarana yang cukup baik dalam menunjang proses latihan. Maka dari penjelasan diatas maka dapat ditarik kesimpulan dari acuan angket penelitian yang diberikan bahwa atlet-atlet Gulat Kabupaten Kerinci pada intinya sangat termotivasi dengan olahraga Gulat, hanya saja akhir-akhir ini atlet mulai merasa jenuh dengan metode latihan yang kurang bervariasi. Pada dasarnya atlet-atlet Gulat Kabupaten Kerinci sangat menyukai latihan yang melatih teknik bantingan, oleh karena itu perlunya pelatih dapat menerapkan latihan teknik bantingan ke dalam tiap sesi latihan.

\section{DAFTAR RUJUKAN}

Ahmad Fitrah Darmawan, Made Pramono. 2017. Analisis SWOT Pembinaan Prestasi Di PGSI (Persatuan Gulat Seluruh Indonesia) KabupatenLamongan. Jurnal Kesehatan Olahraga, 5(2), 19-28. Retrieved from https://jurnalmahasiswa.unesa.ac.id/index.php/jurnalkesehatanolahraga/article/view/17500/15935

Arikunto, S. Prosedur Penelitian. Jakarta, PT Rineka cipta, 1996. 
Depdikbud, Kamus Istilah Olahraga Jakarta, departemen pendidikan dan kebudayaan, 1982

Djoko Pekik Irianto. 2002. Dasar kepelatihan. Yogyakarta: Surat PerjanjianPelaksanaan Penulisan Diktat.

Hadi, R. Teknik Dasar Gulat, Jawa Tengah, 2007

Harsono, Coaching Dan Aspek-Aspek Psikologis dalam coaching, C.V. Tambak Kusuma 1988.

Indrayana, B., \& Yuliawan, E. (2020). Survei Kelayakan Sarana Dan Prasarana pada 31 Cabang Olahraga Anggota Koni Kota Jambi Peserta Pekan Olahraga Provinsi Jambi Ke-23. Jurnal Prestasi, 4(2), 43-48.

PGSI. 1998. Seperempat abad Gulat di Indonesia. Jakarta: Persatuan Gulat Seluruh Indonesia Cabang Jakarta Barat.

Sajoto, M. Pembinaan Dan Peningkatan Kekuatan Kondisi Fisik Dalam Olahraga, Semarang : Dahara Prize, edisi baru, 1995.

Soepartono. 2000. Sarrana dan Prasarana Olahraga. Jakarta: Depdinas.

Yuliawan, E., \& Setiawan, I. B. (2019). SOSIALISASI PENCEGAHAN DAN REHABILITASI CEDERA OLAHRAGA MENGGUNAKAN KINESIO TAPING PADA SEKOLAH SEPAK BOLA LAMBUR. Cerdas Sifa Pendidikan, 8(1), 4755. 